tion to the practical problems encountered in the settingup of a cement industry in Uganda. The Administrators have decided in future to revort to the practice of awarding the Beilby Medal and Prize annually, provided there is a candidate of sufficient merit. The next award will, therefore, be made in 1964.

\section{Alfred P. Sloan Foundation Awards 1963}

Alfred P. Sloan Foundation Awards for the advancement of cancer research have been conferred on the following: Prof. J. W. Berg, associate attending pathologist of the Memorial Hospital for Cancer and Allied Diseases, associate of the Sloan-Kettering Institute for Cancer Research, Division of Pathology, also assistant professor of pathology of the Sloan-Kettering Division of the Graduate School of Medical Sciences, Cornell University Medical College; Dr. J. H. Burchenal, member of the SloanKottering Institute for Cancer Resoarch and ehief of the Division of Clinical Chemothorapy, also attending physician and co-chiof of the Chemotherapy Service of Memorial Hospital for Cancer and Allied Diseases, and professor of medicino at Cornell University Medical College; Dr. J. G. Fortner, associate member of the SloanKettering Institute for Cancer Research, Division of Experimental Surgery, also assistant attending surgeon of Memorial Hospital for Cancer and Allied Diseases, and clinical assistant professor of Surgery at Cornell University Modical College; Prof. Mary L. Potormann, associato member of the Sloan-Kottering Institute for Cancer Research, Division of Nucleo-Protein Chemistry, and also associate professor of biochemistry in the SloanKettering Division of the Graduate School of Modical Sciences, Cornell University Medical College. The awards each consist of a grant of 10,000 dollars.

\section{First Wild Life Exhibition in Britain}

ON May 17 the Right Hon. Lord Hailsham, Minister for Science, will open the first Wild Life Exhibition to be held in Britain. The Exhibition, which is sponsored by the Observer for the Council for Nature, will be hold in the Royal Horticultural Society Halls during May 17-25. The Exhibition has attracted a great deal of interest both in London and the provinces, and will be the focal point of National Nature Week. Many of the most prominent associations interested in conservation of wild life have also taken stands at the Exhibition. Included in the Exhibition are a B.B.C. cinema showing its latest Naturo films; the stand takon by tho Forestry Commission showing the efforts boing made to encourage wild life to live in newly-forested country; the National Trust stand demonstrating their project on Farne Islands for conserving seals and sea birds; the World Wild Life Fund, which will demonstrate the vital noed to conserve the endangered wild life of the world. There will also be a wide range of commercial exhibits, including cumeras, binoculars, books on natural history and camping oquipment. The Council for Nature, with ten of its affiliated societies, will demonstrate their efforts to study and preserve British wild creatures.

\section{Courses of Postgraduate Study at Glasgow}

Coursers of postgraduate study, offored by the Royal College of Science and Technology, Glasgow, are listed in a brochure issued by the College under that title $\left(\mathrm{Pp}_{\mathrm{p}} 28\right.$. Glasgow: The Royal College of Scienco and Technology, 1963). The courses aro opon to Associates of the College, graduates of a university and others who satisfy the Board of Studies that their qualifications are adequate. Courses are offered in mathematics, natural philosophy, chemistry, chemical technology and chemical engineering, metallurgy, mechanical, civil and chemical engineering, electrical engineering, mining engineering, naval architecture, pharmacy, applied microbiology and biology, food science, textile technology, and arohitecture and town planning. The brochure indicates the work covered in the advanced courses and tutorial work.

\section{Announcements}

Prof. Hans A. Bethe, professor of physics at Cormell University, has been awarded tho Rumford Promium of the American Academy of Arts and Sciences for his "contributions to the theory of energy production in stars". Dr. Bethe is the fifty-third recipient of the Premium, which was established in 1796 by Benjamin Thompson, Count Rumford, and which from the beginning consisted of "two medals struck in the same dyo, the one of gold, and the other of silver, and of such dimensions that both of them together may be equal in value . . . to three hundred dollars". At the present time an award of five thousand dollars accompanios the medals.

A List of Publications to December 31, 1962, issued by the Commonwealth Scientific and Industrial Research Organization, Australia, includes publications issued by the Organization and its predecessors (Pp. 55. Melbourne: Commonwealth Scientific and Industrial Research Organization, 1963). Hand-books and monographs are listed first, followed by bulletins, pamphlets, circulars, publications in the Land Research Series, soil publications, divisional publications, liaison publications, annual reports, and research reviews. There is also a subject index.

A colloquium on "Topies in Plant Biochomistry", arranged jointly by the Biochemical Socioty and De Neederlandse Vereniging voor Biochimie, will be held at Leyden during May 16-17. Further information can be obtained from Dr. H. R. V. Arnstein, National Institute for Medical Research, The Ridgeway, Mill Hill, London, N.W.7.

THe seventh international Instrument Show will be held at 4 Tilney Streot, Park Lane, London, W.1, during May 27-31, in conjunction with the first environmental engineering symposium, which will be hold at the Dorchester Hotel, Park Lane, London, W.1, during May 28-30. Further information can be obtained from B. and K. Laboratories, Ltd., 4 Tilney Stroot, Park Lane, London, W.1.

A FOUR-WeEk full-time courso on "Marine Nuclear Propulsion", organized by the Whitehaven College of Further Education, will be held in the College during June 10-July 5. The course will cover the problems involved in placing a reactor in a ship or submarine. Further information can be obtained from the Head of the Physics and Mathematics Dopartment, Whitehaven College of Further Education, Flatt Walks, Whitehaven.

THe sixth carbon conforence, arranged under the auspices of the Amorican Carbon Committee, will be held in the Univorsity of Pittsburgh during June 17-21. The programme will include sessions on: high-temperature and pressure properties; eloctronic properties; mechanical properties; X-ray and electron diffraction studies; formation and reaction of single crystals; radiation damage; kinetics of gas solid reactions; chemistry of carbon-oxygen complexes; pore structure of carbons; pyrolytic graphites; carbon binders; carbon technology. Further information can be obtained from Prof. $\mathrm{S}$. Mrozowski, Carbon Research Building, State University of New York, at Buffalo, 10 Power Drive, Buffalo 14, New York.

ErRatum. It is regrotted that a Note added in proof which should havo been appended to the communication by Dr. J. J. Gilvarry and Dr. A. R. Hochstim, appearing on p. 624 of the February 9 issue of Nature, was erroneously added to the following communication, and hence appeared on p. 626 . 